\title{
Vital Signs Laterality
}

National Cancer Institute

\section{Source}

National Cancer Institute. Vital Signs Laterality. NCI Thesaurus. Code C123975.

A qualifier for the side of the body vital signs test is performed. 